\title{
APLIKASI ASAP CAIR SUREN TERHADAP BAKTERI Xanhtomonas oryzae Pv. oryzae PENYEBAB HAWAR DAUN BAKTERI PADA PADI SECARA IN VITRO
}

\author{
Oleh : \\ Lilih Nurlailah *) \\ Melissa Syamsiah **)
}

\begin{abstract}
Abstrak
Salah satu upaya yang dapat dilakukan untuk meningkatkan produktivitas tanaman padi adalah mengendalikan penyakit secara terpadu. Asap cair suren merupakan suatu inovasi baru yang dapat digunakan karena bahan baku mudah didapat dan mudah dipergunakan. Penelitian ini bertujuan untuk mengetahui pengaruh dari aplikasi asap cair suren terhadap bakteri Xanthomonas oryzae pv. oryzae penyebab hawar daun bakteri pada padi secara in vitro. Penelitian dilaksanakan dengan menggunakan Rancangan Acak Lengkap (RAL) dengan 7 perlakuan setiap perlakuan terdiri dari 4 ulangan. Perlakuan dari penelitian ini yaitu Kontrol (kontrol negatif dengan aquades ), ACS A (asap cair suren dengan konsentrasi 6,25\%), ACS B (asap cair suren dengan konsentrasi 12,5\%), ACS C (asap cair suren dengan konsentrasi 25 $\%$ ), ACS D (asap cair suren dengan konsentrasi $50 \%$ ), ACS E (asap cair suren dengan konsentrasi $100 \%$ ), KF (kontrol positif dengan amoksisilin). Pengamatan diambil 6 jam setelah perlakuan dan pengambilan data dilakukan setiap 6 jam selama 24 jam, dengan parameter pengamatan yaitu; diameter hambatan, luas zona hambatan dan persentase hambatan. Hasil penelitian menunjukan bahwa asap cair suren berpengaruh terhadap parameter; diameter hambatan, luas zona hambatan dan persentase hambatan pertumbuhan bakteri Xanthomonas oryzae pv. oryzae secara in vitro, serta konsentrasi asap cair suren $50 \%$ dan 100\% merupakan konsentrasi yang dapat diaplikasikan karena mulai mampu menghambat perkembangbiakan Xanthomonas oryzae pv. oryzae secara in vitro
\end{abstract}

Kata kunci : asap cair suren, Xanthomonas oryzae pv. oryzae, hawar daun bakteri

\begin{abstract}
One effort that can be done to improve the productivity of the rice plant desease control pest integrated management. Liquid smoke suren is a new innovation that can be used as raw materials easily obtainable and easily used. This research aims to know the influence of Application Suren liquid smoke to Xanthomonas oryzae pv. oryzae Bacterial leaf blight on rice by in vitro. The research was carried out by using a complete Randomized Design (RAL) with 7 treatment each treatment consists of 4 repeats. The treatment of the study is Control (negative control with aquades), ACS A (suren liquid smoke with 6.25\% concentration), ACS B (suren liquid smoke with 12,5\% concentration), ACS C (suren liquid smoke with $25 \%$ concentration), ACS D (suren liquid smoke with 50\% concentration), ACS E (suren liquid smoke with 100\% concentration), KF (positive control with amoksisilin). Observations taken 6 bours after treatment and data retrieval is performed every 6 hours for 24 hours, with observation parameter is; the diameter of the zone barriers, obstacles and barriers percentage. Research results show that liquid smoke suren to parameter; the diameter of the zone barriers, obstacles and barriers the bacterium Xanthomonas oryzae pv. oryzae percentage in vitro as well as concentration of suren liquid smoke $50 \%$ and $100 \%$ concentration which can be applied due to start being able to inbibit breeding bacterium Xanthomonas oryzae pv. oryzae in vitro.
\end{abstract}

Keywords: Suren liquid smoke, Xanthomonas oryzae pv. oryzae, Bacterial leaf blight

\footnotetext{
Aplikasi Asap Cair Suren Terhadap Bakteri Xanhtomonas oryzae Pv. Oryzae Penyebab Hawar Daun Bakteri Pada Padi Secara In Vitro
} 
*) Alumni Fakultas Sains Terapan UNSUR

**) Dosen Fakultas Sains Terapan UNSUR 


\section{PENDAHULUAN}

Upaya untuk memenuhi kebutuhan terhadap produksi padi di Indonesia harus mencapai beberapa peningkatan dari berbagai segi seperti ekonomi, mutu dan produktivitas, yang dapat dicapai dengan penerapan teknologi yang ada dan telah dikembangkan seperti penentuan lahan tanam, pemilihan benih, teknik penanaman, pemeliharaan yang salah satu didalamnya terdapat penanganan hama dan penyakit secara terpadu yang menjadi faktor kritis (Balai Besar Pengkajian dan Pengembangan Teknologi Pertanian, 2016).

Salah satu penyakit utama pada tanaman padi adalah HDB (Hawar Daun Bakteri ). Penyakit ini disebabkan oleh bakteri gram negatif Xanthomonas oryzae pv. oryzae (Wahyudi, 2011). Di Indonesia HDB pertama kali dilaporkan pada tahun 1950. Serangan HDB menyebabkan kerugian hasil panen pada musim hujan sebesar $21-29 \%$ dan pada musim kemarau 18-28\%. Ditahun 2010 luas penularan penyakit HDB mencapai lebih dari 110 . 248 ha, 12 ha diantaranya menyebabkan puso (Suparyono, 1996; Sudir, 2012; Wahyudi, 2011). Tingkat serangan parah HDB terjadi di Jawa Barat seluas 40.486 ha, Jawa Tengah 30.029 ha, Jawa Timur 23.504 ha, Banten 3.745 ha, dan Sulawesi Tenggara 2.678 ha. karakter iklim tropis juga menyebabkan banyak ditemukanya patogen (Wening, 2016).

Xanthomonas oryzae pv. oryzae (Xoo) menyerang padi pada semua fase pertumbuhan mulai dari fase persemaian sampai menjelang panen, menginfeksi tanaman padi pada bagian daun melalui luka daun atau lubang alami berupa stomata dan merusak klorofil daun. Kondisi ini menyebabkan kemampuan tanaman dalam fotosintesis menurun. Apabila penularan penyakit terjadi pada fase generatif maka proses pengisian gabah kurang sempurna (Puspitasari, 2014).

Penggunaan Pestisida sintetik sebagai solusi dari penyakit HDB dikhawatirkan akan mencemari lingkungan, serta dapat memacu terjadi resistensi dan memunculkan hama sekunder. Pengunaan pestisida organik yang berasal dari bahan alami yang mudah terdegradasi didalam sehingga dampak residunya tidak signifikan dan mampu mengendalikan organisme pengganggu tanaman (Pusat pelatihan dan pengembangan perkebunan, 2012). Karena waktu simpan yang relatif singkat membuat diadakannya inovasi baru yaitu dibuat sebagai asap cair yang merupakan hasil kondensasi uap hasil pembakaran bahan langsung maupun tidak langsung dari bahan yang banyak mengandung karbon dan senyawa lainnya. Asap cair mangandung berbagai senyawa yang terbentuk karena terjadinya pirolisis tiga bahan utama yaitu selulosa, hemiselulosa dan lignin (Yunus, 2011). Dilihat dari proses ekstraksi bagian untuk mengoptimalkan kandungan utama suren (asam asetat dan fenol) yaitu dengan proses mengkondensasi asap hasil pembakaran suren sehingga didapat campuran larutan hasil dispersi asap dalam air yang dapat disebut asap cair suren (Yeprida, 2008). Asap cair suren dapat menjadi solusi untuk meminimalisir penggunaan pestisida sintetik, yang berfungsi sebagai anti bakteri, serta mencegah terjadinya pencemaran lingkungan, resistensi dan resurgensi hama (Pusat Pelatihan Pertanian, 2015).

Berdasarkan latar belakang di atas dilakukan penelitian dengan tujuan : Mengetahui pengaruh aplikasi asap cair suren terhadap diameter hambatan, luas zona hambat dan persentase hambatan pertumbuhan bakteri Xantomonas oryzae pv. oryzae penyebab hawar daun bakteri pada padi secara in vitro.

\section{METODE PENELITIAN}

\section{Waktu dan Tempat}

Penelitian ini dilaksanakan di dua tempat yaitu Balai Penelitian Tanaman Hias (BALITHI) Segunung tepatnya di bagian biokontrol sebagai tempat 
pembuatan asap cair suren serta labolatorium bakteriologi sebagai tempat pembuatan biakan bakteri Xanthomonas oryzae pv. oryzae (Xoo), tempat pengaplikasian dan pengamatan penelitian. Serta di Kampung Kubang, Desa Sukadana, Kecamatan Campaka sebagai tempat pesiapan bahan. Waktu penelitian dimulai dari bulan Februari 2018 sampai dengan Mei 2018.

\section{Alat dan Bahan}

Penelitian ini menggunakan alat dan bahan percobaan yang terdiri dari :

a. Isolasi dan Perbanyakan Xanthomonas oryzae pv. oryzae (Xoo)

Alat yang digunakan adalah kompor listrik, magnetic stirrer, pengaduk, cawan petri, botol erlenmeyer, botol ukur, mikro pipet, tabung reaksi, dan bahan yang digunakan adalah alkohol, kapas, para film, daun padi Cintanur yang terinfeksi HDB diambil dari kecamatan Cianjur, nutrient agar (NA) media ini digunakan karena selain mampu menumbuhkan bakteri Xoo juga mengefisienkan biaya, aquades.

b. Pembuatan Asap cair suren Alat produksi asap cair (wadah stainless steel, kompor, kondensor, Erlenmeyer, aerator, selang, lem besi), termometer, wadah plastik, gelas ukur, stopwatch, aluminium foil, botol viala, tisu, kompor semawar, tabung gas, tungku, gentong air, karung, pisau, dan alat-alat gelas lainnya. Bahan dasar yang digunakan untuk pembuatan asap cair adalah limbah kayu suren. akuades dan bahan bakar LPG.

c. Pembuatan Nutrient Agar (NA) sebagai media pembiakan bakteri dan perlakuan.

\section{Pembuatan}

NA menggunakan alat sebagai berikut, kompor elektrik, tabung reaksi, pipet tetes, cawan petri, pengaduk, gelas ukur dan menggunakan bahan Nutrient Agar (NA) dan aquades. Media NA merupakan salah satu media yang dapat digunakan untuk perbanyakan bakteri Xoo (Anisah, 2015).

d. Identifikasian Xanthomonas oryzae pv. oryzae

Alat yang digunakan adalah cawan petri, jarum ose, inkubator, dan bahan yang digunakan adalah NA, LAF (laminar air flow), tanaman tembakau, kentang, mikroskop elektron.

e. Alat dan Bahan Tambahan

Alat yang akan digunakan terdiri dari botol erlemeyer, LAF (Erik, 2013), jarum ose, autoclave, alumunium foil, kapas steril, cawan petri, timbangan digital, tabung ukur, panci, kompor, papan nama, alat tulis, jangka sorong, kamera digital, penggaris, $\mathrm{pH}$ meter dan bahan tambahan berupa alkohol 70\% , spirtus, air steril, aquades, kertas cakram ukuran $5 \mathrm{~mm}$.

\section{Tahapan Penelitian}

Penelitian ini merupakan penelitian eksperimental labolatorik melalui metode disk diffusion untuk melihat potensi aplikasi asap cair suren terhadap hawar daun yang disebabkan oleh bakteri Xanthomonas oryzae pv. oryzae dengan menggunakan media Nutrient Agar (NA). Disk Diffusion Method

Disk diffusion method adalah salah satu metode standar yang digunakan untuk melihat sensitivitas suatu isolat bakteri, dilihat dari cincin yang terbentuk disekitar bakteri atau pada bakteri itu setelah aplikasi perlakuan (Tendencia, 2004). Metode difusi yang digunakan adalah metode cakram yaitu dengan cara menginokulasi bakteri uji dicawan petri dan membiarkan senyawa yang mengandung anti bakteri berdifusi ke dalam agar (Anisah, 2014).

Pembuatan Isolat Xanthomonas oryzae pv. oryzae

1. Isolasi Xanthomonas oryzae pv. oryzae

a. Inokulum Xanthomonas oryzae pv. oryzae diisolasi dari daun padi yang memperlihatkan gejala hawar daun bakteri (sakit), daun sehat yang ada di 
rumpun yang sama dan tanah yang tepat berada di bawahnya.

b. Daun padi yang bergejala HDB dicuci, daun padi sehat di air yang mengalir lalu kering anginkan. Tanah dimasukan ke dalam plastik bening lalu diisi air dan dicampurkan.

c. Daun padi sehat dan sakit yang telah kering anginkan kemudian dibersihkan lagi menggunakan alkohol. Selanjutnya seleksi dan potong bagian daun yang akan gunakan menggunakan gunting stainless.

d. Bakteri diisolasi dengan cara menggerus material daun padi sakit, daun padi sehat dan tanah pada mortar yang berbeda hingga halus.

e. Kemudian ditambahkan $1 \mathrm{ml}$ air steril (aquades), sehingga diharapkan bakteri yang berada dalam jaringan tanaman dapat terlepas.

2. Menumbuhkan Bakteri pada Medium NA

a. Media NA dicairkan menggunakan kompor elektrik yang telah disiapkan sebelumnya.

b. LAF dinyalakan dan media NA dituangkan yang telah cair dengan suhu telah mencapai $\pm 45^{\circ} \mathrm{C}$ ke dalam cawan petri, setelah media NA mengeras kemudian disiapkan daun padi sakit, daun padi sehat, dan tanah yang telah digerus halus di mortar simpan di dalam LAF.

c. Bunsen dinyalakan dan siapkan

d. Alkohol di botol kaca kecil kemudian panaskan jarum ose hingga berwarna merah kemudian celupkan ke dalam alkohol ulangi sampai tiga kali dan yang terakhir ketika jarum ose telah berwarna merah pengurangan suhu dilakukan dengan cara menyentuhkannya ke dalam media NA yang ada di cawan petri bagian pinggirnya.

e. Diambil masing - masing satu ose cairan daun padi yang bergejala HDB, daun padi sehat dan tanah kemudian oleskan ke media NA dengan metode garis kuadran dengan total 6 cawan. Setelah itu diberi label dan disimpan di dalam inkubator selama 24 jam karena koloni belum terlihat jelas maka ditambah menjadi 48 jam dengan suhu $30^{\circ} \mathrm{C}$ (Herawati, 2016).

3. Pemurnian Bakteri Xanthomonas oryzae pv. oryzae (Xoo)

a. Isolat bakteri ditumbuhkan dalam media sebanyak satu jarum ose steril (Herawati, 2016).

b. Setelah itu disimpan ke dalam inkubator selama 48 jam dengan suhu $30^{\circ} \mathrm{C}$.

c. Setelah inkubasi, bakteri yang tumbuh diambil dari koloni tunggal yang terpisah dengan menggunakan ose steril (Wahyudi, 2011).

d. Proses ini membutuhkan waktu 13 hari sampai bakteri Xoo, setelah itu bakteri yang tumbuh diuji patogenisitasnya mengggunakan tanaman tembakau dan umbi kentang dengan cara diencerkan terlebih dahulu kemudian disuntikan ke permukaan daun, untuk daun padi tidak disuntikan tapi dioleskan menggunakan kapas steril dan untuk umbi kentang langsung diletakan dipermukaan (Lubis, 2013). Kemudian dipindahkan ke media NA yang baru di cawan petri.

e. Diketahui setelah 24 jam bahwa bakteri Xoo yang berasal dari padi cintanur di kecamatan Cianjur tidak mempunyai daya virulensi yang tinggi sehingga dikatagorikan tidak ganas hal ini diketahui dari uji patogenisitas yang tidak menunjukan nekrotik.

4. Karakteristik Fisiologi dan Biokimia

a. Koloni bakteri yang murni diuji reaksi gramnya, apakah termasuk bakteri gram positif atau gram negatif.

b. Koloni bakteri diambil dari biakan murni pada medium NA dengan menggunakan jarum ose kemudian diletakkan di atas gelas preparat yang telah ditetesi larutan $\mathrm{KOH} 3 \%$. 
c. Secara teratur koloni bakteri dan larutan tersebut diaduk dengan jarum ose hingga benar-benar tercampur sambil diangkat-angkat setinggi 0,5 $1 \mathrm{~cm}$.

d. Koloni yang nampak berlendir dan melekat menunjukkan adanya reaksi positif yang menunjukkan bakteri tersebut tergolong Gram Negatif (G)

e. Bakteri Xanthomonas oryzae pv. oryzae memperlihatkan reaksi positif yaitu berlendir dan melekat sehingga bakteri ini termasuk Gram Negatif (G-).

f. Dilihat bentuk dari bakteri Xoo menggunakan mikroskop elektron dan diketahui memiliki bentuk batang.

\section{Pembuatan Asap Cair Suren}

1. Asap cair suren dibuat dengan cara yang pertama dilakukan berupa pemotongan bagian suren, bagian yang digunakan adalah batang dan kulit suren. Alasan penggunaan bagian ini karena merupakan limbah yang jarang dimanfaatkan oleh masyarakat. Ukuran lebih kecil akan memperbesar luas permukaan.

2. Kayu suren yang telah dikeringkan selama \pm 5 hari dimasukan ke wadah stainless steel sebagai tungku pirolisis, kemudian ditutup untuk pirolisa.

3. Dilakukan perbaikan alat untuk pirolisi dahulu dikarenakan sudah lama tidak dipakai. Sehingga menggunakan wadah stainless steel yang baru dan dipakaikan lem besi pada setiap sambungan wadah agar asap tidak keluar.

4. Rangkaian alat kondensasi dipasang dan tabung pendingin dialiri dengan air secara terus menerus selama proses pirolisis terjadi.

5. Api kompor dinyalakan, bahan yang ada dalam wadah akan panas dan akan mengalami pirolisis.

6. Asap akan keluar dari wadah dan masuk kondensor yang akhirnya mengeluarkan cairan hasil kondensasi.
7. Pemanasan diakhiri sampai tidak ada asap cair yang menetes dalam wadah penampung (Yeprida, 2008).

8. Proses pemanasan membutuhkan waktu 16 jam dikarenakan asap cair yang dibutuhkan adalah $320 \mathrm{ml}$ pada waktu 8 jam asap cair suren yang dihasilkan sebanyak $160 \mathrm{ml}$.

9. Asap cair suren hasil pirolisis kemudian dimurnikan dengan proses filtrasi (Maryani, 2014) atau disaring menggunakan millipore dengan ukuran $0,2 \mu \mathrm{l}$ alat ini digunakan untuk mensterilkan asap cair suren dari mikroorganisme yang terbawa dan memisahkan asap cair dari karbon hasil pembakaran, pengambilannya menggunakan suntikan steril dengan kapasitas $10 \mathrm{ml}$.

Pembuatan media Nutrient Agar (NA)

1. disiapkan bubuk Nutrient Agar (NA) sebanyak 200 gram.

2. Setelah didihkan, larutan NA dimasukkan ke dalam erlenmayer kemudian ditutup dengan kapas steril dan ditutup lagi dengan menggunakan aluminium foil.

3. Kemudian disterilkan di dalam autoclave selama kurang lebih 15 menit dengan suhu $121-124^{\circ} \mathrm{C}$ pada tekanan 1,25 atm. Setelah itu NA dikeluarkan dan dibiarkan hingga dingin $\left(10-20{ }^{\circ} \mathrm{C}\right)$.

4. Kemudian dituangkan ke dalam cawan petri dan jika akan dijadikan stok maka disimpan dilemari pendingin ketika digunakan nanti dipanaskan terlebih dahulu supaya media NA mencair.

Aplikasi Asap Cair Suren Terhadap Bakteri Xoo

Asap cair suren diaplikasikan pada Bakteri Xoo, pengaplikasiannya menggunakan metode yang dilakukan dengan cara :

1. Media NA dipanaskan selama 15 menit menggunakan kompor elektrik kemudian setelah mencair dibiarkan sampai suhu $\pm 45^{\circ} \mathrm{C}$. 
2. Sambil menunggu media dingin disiapkan inokulum bakteri Xoo yang telah dibiakan sebelumnya di media NA selama 48 jam, terlebih dahulu diencerkan 1 - 2 kali (Ardani, 2010). Cara membuatan kepadatan bakteri adalah mengambil satu ose biakan Bakteri Xoo masukan ke dalam tabung reaksi, vortek sampai homogen. Ambil $100 \mu \mathrm{L}$ Bakteri Xoo yang telah diencerkan dimasukan ke dalam tabung reaksi baru kemudian vortek lagi

3. Setelah selesai masukan $100 \mu \mathrm{L}$ suspensi bakteri Xoo ke dalam media NA yang telah mencapai suhu $\pm 45^{\circ} \mathrm{C}$ campurkan sampai merata.

4. Kemudian dituangkan ke dalam 24 cawan petri yang telah diberi garis tunggu sampai mengeras.

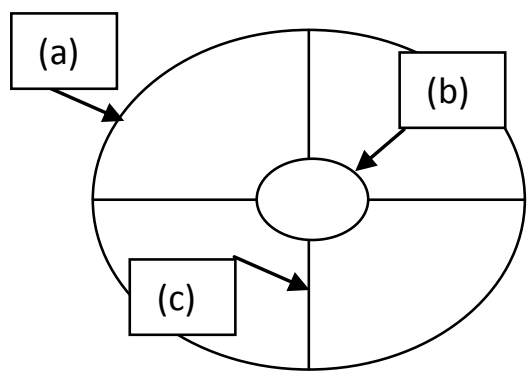

Gambar 1 (a) cawan petri, (b) kertas cakram, (c) garis pembatas

5. Selanjutnya dicelupkan 4 kertas cakram steril berdiameter $5 \mathrm{~mm}$ ke dalam setiap perlakuan yaitu pada aquades (kontrol negatif) konsentrasi asap cair suren $6.25 \%, 12.5 \%, 25 \%$, $50 \%, 100 \%$ dan amoksisislin (kontrol positif) dengan konsentrasi $25 \mathrm{mg} / 5$ $\mathrm{ml}$ (Kaur, 2011). Kemudian diletakan di tengah semua cawan petri yang telah diberi nama sesuai dengan perlakuan yang digunakan.

6. Setelah itu dilakukan pengamatan dengan mengukur diameter hambatan, luas zona hambat, dan persentase zona hambat. Data yang diambil setiap 6 jam sekali selama 24 jam.

\section{Rancangan Penelitian}

Rancangan penelitian ini menggunakan Rancangan Acak Lengkap (RAL) satu faktor atau non faktorial yang terdiri dari 7 perlakuan. Setiap perlakuan terdiri dari dengan 4 ulangan. Perlakuan tersebut yaitu :

1. Kontrol $=$ Aquades (kontrol negatif)

2. ACS A = Asap cair suren dengan konsentrasi $6.25 \%$

3. ACS $\mathrm{B}=$ Asap cair suren dengan konsentrasi $12.5 \%$

4. ACS $\mathrm{C}=$ Asap cair suren dengan konsentrasi $25 \%$

5. ACS D = Asap cair suren dengan konsentrasi $50 \%$

6. ACS $\mathrm{E}=$ Asap cair suren dengan konsentrasi $100 \%$

7. Kontrol $\mathrm{F}=$ Amoksisilin (kontrol positif)

Parameter yang diamati meliputi: diameter hambatan, luas zona hambat dan persentase hambatan asap cair suren terhadap bakteri Xoo penyebab Hawar Daun Bakteri pada padi secara in vitro.

\section{Pengolahan Data}

Data yang diperoleh dari hasil pengamatan penelitian diolah menggunakan Komputer dengan bantuan software Minitab dan Microsoft Excel. Data hasil pengolahan kemudian dianalisa melalui tabel Anova atau tabel sidik ragam, dengan Uji beda nyata percobaan menggunakan Uji Tukey pada alpha 5\%.

\section{HASIL DAN PEMBAHASAN}

\section{Hasil Pembuatan Asap Cair Suren}

Prinsip yang digunakan dalam produksi asap cair suren adalah metode Kondensasi atau pirolisis. Volume asap cair hasil kondensasi $320 \mathrm{ml}$ yang dihasilkan dari 5000 gram limbah suren dengan durasi waktu produksi 2 × 8 jam Menurut Anisah (2014) Randemen diukur berdasarkan volume kondensat yang dihasilkan (ml) dan setiap satuan berat bahan yang dibakar

Randemen asap cair $=\underline{320 \mathrm{ml}} \times 100 \%$ $=6,4 \% \quad 5000$ gram 
Prinsip dasar pembuatan asap cair suren adalah metode pirolisis dan filtrasi (Fauzan, 2017). Pirolisis adalah proses kondensasi atau perubahan gas menjadi wujud lain yaitu cairan yang didapat dari hasil pembakaran material langsung maupun tidak langsung, tanpa melibatkan oksigen dan bahan kimia lain (Yeprida, 2008; Firman, 2016) dan filtrasi adalah proses pemisahan solid-liquid dengan cara melewatkan liquid melalui media berpori atau bahan-bahan berfori untuk untuk memisahkan butiran-butiran halus zat padat yang tersuspensi dari liquida (Widyastuti, 2011). Penggunaan millipore digunakan untuk sterilisasi mekanik. Millipore terbuat dari membran selulosa asetat dan mimiliki tingkat penyaringan yang tinggi sehingga lebih baik dari saringan lain (Suprihatin, 2004). Randemen yang dihasilkan asap cair suren tergolong cukup baik karena menurut Anisah (2014) dan Aryani (2015) bahwa asap hasil pirolisis terbagi 3 berdasarkan suhu yaitu $200-250^{\circ} \mathrm{C}$ randemen $3,1 \%$, $\mathrm{pH} 3,35$ warna coklat terang, asam asetat 2,4588\%, fenol 9.975,65 ppm; di suhu 280 - $350^{\circ}$ randemen 9,8\%, pH 2,80, warna kuning kecoklatan, asam asetat $4,8173 \%$, fenol 24.854,56 ppm; dan suhu $>400^{\circ} \mathrm{C}$, randemennya $11,3 \%, \mathrm{pH} \quad 2,62$, warna kuning coklat, asam asetat $8,896 \%$, fenol $37.228,85$ ppm. Sehingga dapat digolongkan bahwa asap cair suren yang memiliki randemen 6,4\%, memiliki nilai $\mathrm{pH}$ yang cukup asam, asam asetat dengan konsentrasi cukup tinggi dan kadar fenol yang sedang sehingga dapat digunakan sebagai anti bakteri karena sesuai dengan penelitian sebelumnya.

\section{Hasil Isolasi Xanthomonas oryzae pv. oryzae}

Bakteri Xoo diperoleh melalui proses isolasi dari daun tanaman padi sintanur yang didapatkan dari kecamatan cianjur yang terindikasi terinfeksi Xoo. Hasil identifikasi dari pengujian bakteri menunjukan bakwa bakteri Xoo adalah bakteri gram negatif karena setelah ditetesi $\mathrm{KOH} \mathrm{3 \%}$ menunjukan reaksi berlendir dan melekat yang mengidentifikasikan bakteri Xoo, secara teori bakteri gram positif memiliki dinding sel yang tebal dan memiliki sedikit lemak sedangkan bakeri gram negatif memiliki dinding sel yang lebih tipis serta memiliki lebih banyak lemak.

$\mathrm{KOH} 3 \%$ dapat melisiskan dinding sel bakteri gram negatif sehingga menyebabkan materi DNA pada bakteri keluar dan menunjukan reaksi berlendir dan melekat (Purwohadisantoso, 2009; Fitriani, 2016). Selanjutnya dilakukan pengamatan di bawah mikroskop yang menunjukan berbentuk batang pendek dan memiliki satu flagel, hal ini sesuai dengan ciri - ciri bakteri Xoo dilihat dari gambar 4.2 dan gambar 4.3 dan setelah dibandingkan dengan referensi gambar 4.4 maka mengidenfikasikan positif bakteri Xoo.

Bakteri Xoo mempunyai ciri - ciri sebagai berikut sel berbentuk batang pendek, tidak membentuk spora dan bisa bergerak (moti) dengan 1 flagel. Sel-sel individu ukurannya bervariasi dengan panjang sekitar $0,7 \mu \mathrm{m}-2,0 \mu \mathrm{m}$ dan lebar sekitar $0,4 \mu \mathrm{m}-0,7 \mu \mathrm{m}$. Bakteri Xoo termasuk gram negatif (Bradbury, 1984 dalam Sullivan, 2011).

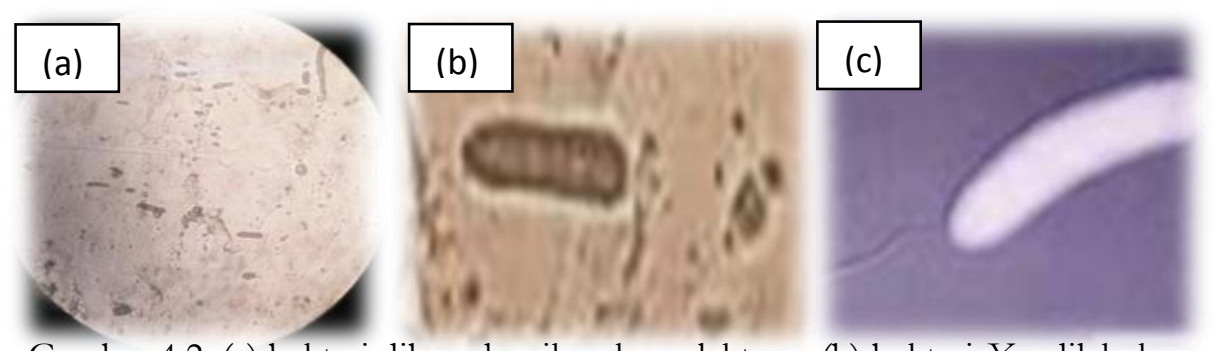

Gambar 4.2. (a) bakteri dibawah mikroskop elektron, (b) bakteri Xoo dilakukan pembesaran, (c) bentuk bakteri Xoo (sumber : Puspitasari, 2014) 


\section{Aplikasi Asap Cair Suren Terhadap Xanhtomonas oryzae pv. oryzae Secara In vitro}

\section{Diameter Hambatan}

Parameter penelitian aplikasi asap cair suren terhadap Xanthomonas oryzae pv. oryzae yang pertama adalah diameter hambatan. Pada Grafik 4.1 dapat dilihat bahwa pengamatan yang dilakukan pada waktu 6 dan 12 jam belum menunjukkan adanya nilai diameter hambatan yang terukur pada semua konsentrasi yang diberikan. Besarnya nilai diameter hambatan baru terukur pada waktu 18 dan 24 jam dengan nilai yang tetap tetapi yang memberikan pengaruh hanya pada konsentrasi $50 \%, \quad 100 \%$ dan kontrol positif amoksisilin. Hal ini sesuai dengan Rijayanti (2014) yang menyebutkan bahwa terbentuknya zona hambat

dalam mekanisme kerja antibiotik hanya satu kali dalam rentang waktu kurang dari 24 jam.

Hasil pengolahan data melalui tabel ANOVA (Analysis of Variance) pada taraf $\propto 5 \%$ nilai $\mathrm{P}$ value lebih kecil dari 0,05 dengan demikian dapat disimpulkan bahwa perlakuan aplikasi konsentrasi asap cair suren berpengaruh terhadap diameter hambatan bakteri Xoo. Terdapat pengaruh aplikasi asap cair suren terhadap diameter pertumbuhan bakteri Xanthomonas oryzae pv. oryzae penyebab hawar daun bakteri pada padi secara in vitro.
Tabel 1 Rata-rata diameter hambatan Xanthomonas oryzae pv. oryzae pada setiap perlakuan.

\begin{tabular}{clcc}
\hline No. & \multicolumn{1}{c}{ Perlakuan } & $\begin{array}{c}\text { Rata-rata } \\
\text { diameter } \\
\text { hambatan } \\
(\mathrm{mm})\end{array}$ \\
\hline 1 & $\begin{array}{l}\text { Aquades (kontrol } \\
\text { negatif) }\end{array}$ & $0.00 \quad \mathrm{c}$ \\
2 & $\begin{array}{l}\text { Asap cair suren } \\
\text { 6.25\% }\end{array}$ & $0.00 \quad \mathrm{c}$ \\
3 & $\begin{array}{l}\text { Asap cair suren } \\
12.5 \%\end{array}$ & $0.00 \quad \mathrm{c}$ \\
4 & $\begin{array}{l}\text { Asap cair suren } \\
25 \%\end{array}$ & $0.00 \quad \mathrm{c}$ \\
5 & $\begin{array}{l}\text { Asap cair suren } \\
50 \%\end{array}$ & $7.700 \quad \mathrm{~b}$ \\
6 & $\begin{array}{l}\text { Asap cair suren } \\
100 \%\end{array}$ & $8.060 \quad \mathrm{~b}$ \\
7 & $\begin{array}{l}\text { Amoksisilin } \\
\text { (kontrol positif) }\end{array}$ & $10.965 \mathrm{a}$ \\
\hline
\end{tabular}

Ket: Angka - angka yang berada pada baris yang sama dan diikuti oleh huruf yang sama berarti tidak berbeda nyata berdasarkan uji tukey pada taraf kepercayaan 5\%

Berdasarkan hasil penelitian amoksisilin (kontrol positif) merupakan perlakuan yang memberikan hasil diameter hambatan terhadap pertumbuhan bakteri Xoo paling besar yaitu $10.965 \mathrm{~mm}$. Perlakuan ini berbeda nyata dengan keenam perlakuan lainnya. Hal ini disebabkan bahan aktif yang terkandung dalam amoksisilin sudah teruji keefektifannya melawan bakteri gram negatif maupun positif Amoksisilin merupakan obat semisintetis yang termasuk dalam antibiotik kelas penisilin (antibiotik beta-laktam). Karena ukurannya lebih kecil sehingga efektif untuk mengendalikan infeksi yang disebabkan oleh bakteri gram positif dan bakteri gram negatif. Obat golongan penisilin, menghambat pertumbuhan bakteri dengan mengganggu reaksi transpeptidasi sintesis dinding sel bakteri. Dinding sel adalah lapisan luar yang rigid yang unik pada setiap spesies bakteri. Dengan terhambatnya reaksi ini maka 
akan menghentikan sintesis peptidoglikan dan mematikan bakteri (Anisah, 2014)

Perlakuan 6 yaitu ACS E (asap cair suren konsentrasi 100\%) merupakan perlakuan aplikasi yang memberikan hasil diameter hambatan pertumbuhan bakteri Xoo yaitu $8.06 \mathrm{~mm}$. Perlakuan ini tidak berbeda nyata dengan perlakuan 5 yaitu ACS D (asap cair suren 50\%) dengan diameter hambatan $7.70 \mathrm{~mm}$.

Hal ini disebabkan asap cair suren memiliki aktifitas antibakteri pada konsentrasi optimum tertentu untuk menghambat aktifitas bakteri Xoo. Yaitu kandungan fenol, asam asetat dan asam asam organik yang terkandung yang mempunyai daya kerja sebagai bakteriosidal yaitu membunuh atau membasmi bakteri secara langsung dan juga bakteriostatik yaitu menghambat atau menekan pertumbuhan bakteri. Dengan mekanisme kerjanya membocorkan dinding sel bakteri (Kaur, 2011).

Akan tetapi perlakuan Perlakuan 6 yaitu ACS E (asap cair suren konsentrasi $100 \%)$ berbeda nyata dengan perlakuan 1 yaitu kontrol (aquades kontrol negatif), perlakuan 2 yaitu ACS A (asap cair suren 6.25\%), perlakuan 3 yaitu ACS B (asap cair suren $12.5 \%$ ) dan perlakuan 4 yaitu ACS C (asap cair suren 25\%). Dikarenakan konsentrasi rendah dan tidak mampu untuk membuat zona hambat sehingga perlakuan tidak berpengaruh. Sejalan dengan Shinta (2017) konsentarasi fenol yang rendah tidak dapat melisiskan dinding sel bakteri, karena pada konsentrasi rendah asap cair bersifat bakteriostatik sehingga belum mampu menghambat pertumbuhan bakteri.

Perlakuan 1 Aquades (kontrol negatif) tidak akan menghambat pertumbuhan bakteri Xoo, karena media NA hanya digunakan untuk menumbuhkan bakteri tanpa diberi zat anti bakteri baik asap cair suren maupun amoksisilin, sehingga bakteri tumbuh tanpa ada hambatan karena memenuhi kondisi lingkungan sesuai dengan syarat tumbuh bakteri Xoo (OEPP/EPPO, 2007).

\section{Luas Zona Hambatan}

Besarnya nilai luas zona hambatan baru terukur pada waktu 18 dan 24 jam dengan nilai yang tetap tetapi yang memberikan pengaruh hanya pada konsentrasi $50 \%, 100 \%$ dan kontrol positif amoksisilin. Hal ini sesuai dengan teori Rijayanti (2014) yang menyebutkan bahwa terbentuknya zona hambat dalam mekanisme kerja antibiotik hanya satu kali dalam rentang waktu kurang dari 24 jam. Luas zona hambatan didapatkan dengan menggunakan rumus $\mathrm{L}=\pi \cdot 1 / 4 \cdot d^{2}$.

Hasil pengolahan data melalui table ANOVA (Analysis of $V$ ariance) pada taraf $\alpha 5 \%$ nilai $\mathrm{F}$ hitung 25.57 dan nilai $\mathrm{p}$ value 0,000 lebih kecil dari alpa 0,05 dengan demikian dapat disimpulkan bahwa perlakuan aplikasi konsentrasi asap cair suren berpengaruh terhadap luas zona hambatan bakteri Xoo.

Berikut ini adalah data hasil ratarata pengaruh aplikasi asap cair suren terhadap luas zona hambatan bakteri Xoo pada waktu 6 dan 12 jam belum terbentuk luas zona hambat pada semua perlakuan dan pada kontrol positif dan setelah pengamatan 18 dan 24 jam baru terlihat zona hambat yang terbentuk dengan hasil yang tidak mengalami perubahan. Hal ini sesuai dengan Rijayanti (2014) yang menyebutkan bahwa terbentuknya zona hambat dalam mekanisme kerja antibiotik hanya satu kali dalam rentang waktu kurang dari 24 jam. 
Tabel 2. Rata-rata luas zona hambatan

\begin{tabular}{clcc}
\hline No. & \multicolumn{1}{c}{ Perlakuan } & $\begin{array}{c}\text { Rata-rata luas } \\
\text { zona } \\
\text { hambatan } \\
\left(\mathrm{mm}^{2}\right)\end{array}$ \\
\hline 1 & $\begin{array}{l}\text { Aquades (kontrol } \\
\text { negatif) }\end{array}$ & 0.00 & $\mathrm{c}$ \\
2 & $\begin{array}{l}\text { Asap cair suren } \\
\text { 6.25\% }\end{array}$ & 0.00 & $\mathrm{c}$ \\
3 & $\begin{array}{l}\text { Asap cair suren } \\
12.5 \%\end{array}$ & 0.00 & $\mathrm{c}$ \\
4 & $\begin{array}{l}\text { Asap cair suren } \\
25 \%\end{array}$ & 0.00 & $\mathrm{c}$ \\
5 & $\begin{array}{l}\text { Asap cair suren } \\
50 \%\end{array}$ & 47.09 & $\mathrm{~b}$ \\
6 & $\begin{array}{l}\text { Asap cair suren } \\
100 \%\end{array}$ & 51.74 & $\mathrm{~b}$ \\
7 & $\begin{array}{l}\text { Amoksisilin } \\
\text { (kontrol positif) }\end{array}$ & 97.01 & $\mathrm{a}$ \\
\hline Ket: Angkan
\end{tabular}

Ket: Angka - angka yang berada pada baris yang sama dan diikuti oleh huruf yang sama berarti tidak berbeda nyata berdasarkan uji tukey pada taraf kepercayaan 5\%

Tabel 2. menunjukkan perlakuan amoksisilin (kontrol positif) merupakan perlakuan yang memberikan hasil luas zona hambatan terhadap pertumbuhan bakteri Xoo paling besar yaitu $97.01 \mathrm{~mm}^{2}$. Perlakuan ini berbeda nyata dengan keenam perlakuan lainnya. amoksisilin merupakan salah satu turunan penisilin, yang mempunyai mekanisme kerja dengan menghambat selektif dinding sel bakteri dengan cara penghambatan pada enzim transpeptidase. Selain itu menurut Anisah (2014) bahwa, bakteri mempunyai lapisan luar yang disebut dinding sel, yang berfungsi untuk mempertahankan bentuk mikroorganisme, dan pelindung sel bakteri yang mempunyai tekanan osmotik internal yang tinggi, trauma pada dinding sel atau penghambatan pembentukannya dapat menyebabkan lisis sel bakteri.

Perlakuan 6 yaitu ACS E (asap cair suren konsentrasi 100\%) memberikan hasil luas zona hambatan pertumbuhan bakteri Xoo yaitu $51.74 \mathrm{~mm}^{2}$. Perlakuan ini tidak berbeda nyata dengan perlakuan
5 yaitu ACS D (asap cair suren 50\%) dengan luas zona hambatan $47.09 \mathrm{~mm}^{2}$.

Karena memiliki kandungan fenol, derivate fenol, asam asetat dan asam - asam organik yang yang relatife tinggi dapat menyebkan lisisnya dinding sel baik karena trauma yang ditimbulkan serta menghambat terbentuknya dinding sel bakteri (Kaur, 2011).

Akan tetapi perlakuan Perlakuan 6 yaitu ACS E (asap cair suren konsentrasi $100 \%$ ) berbeda nyata dengan perlakuan 1 yaitu kontrol (aquades kontrol negatif), perlakuan 2 yaitu ACS A (asap cair suren 6.25\%), perlakuan 3 yaitu ACS B (asap cair suren $12.5 \%$ ) dan perlakuan 4 yaitu ACS C (asap cair suren 25\%). Dikarenakan konsetrasi rendah dan tidak mamapu untuk membuat zona hambat sehingga perlakuan tidak berpengaruh. Sejalan dengan Shinta (2017) konsentarasi fenol yang rendah tidak dapat melisiskan dinding sel bakteri, karena pada konsentrasi rendah asap cair bersifat bakteriostatik menghambat pertumbuhan bakteri saja, atau belum mampu bersifat bakteriosidal yaitu membunuh bakteri secara langsung.

Sama halnya dengan perlakuan Aquades steril (kontrol negatif) tidak akan menghambat pertumbuhan bakteri Xoo, karena media NA hanya digunakan untuk menumbuhkan bakteri tanpa diberi zat anti bakteri baik asap cair suren maupun amoksisilin, sehingga bakteri tumbuh tanpa ada hambatan karena memenuhi kondisi lingkungan sesuai dengan syarat tumbuh bakteri Xoo (OEPP/EPPO, 2007).

\section{Persentase Hambatan}

Besarnya nilai persentase hambatan baru terukur pada waktu 18 dan 24 jam dengan nilai yang tetap tetapi yang memberikan pengaruh hanya pada konsentrasi $50 \%, 100 \%$ dan kontrol positif amoksisilin. Hal ini sesuai dengan Rijayanti (2014) yang menyebutkan bahwa terbentuknya zona hambat dalam mekanisme kerja antibiotik hanya satu kali dalam rentang waktu kurang dari 24 jam. 
Persentase penghambatan dihitung dengan rumus yang mengacu pada (Pandey et al., 1982 dalam Zanbonelli et al., 1996) yaitu : $\mathrm{X}=\mathrm{b} / \mathrm{a} \times 100 \%$.

Hasil pengolahan data melalui tabel ANOVA (Analysis of Variance) pada taraf $\alpha 5 \%$ nilai $\mathrm{P}$ value lebih kecil dari 0,05 dengan demikian terdapat pengaruh aplikasi asap cair suren terhadap persentase hambatan pertumbuhan bakteri Xanthomonas oryzae pv. oryzae penyebab hawar daun pada padi secara in vitro.

Berikut ini adalah data hasil ratarata pengaruh aplikasi asap cair suren terhadap persentase hambatan Xanthomonas oryzae pv. Oryzae pada waktu pengamatan 18 dan 24 jam dengan hasil yang tidak mengalami perubahan. Hal ini sesuai dengan teori Rijayanti (2014) yang menyebutkan bahwa terbentuknya zona hambat dalam mekanisme kerja antibiotik hanya satu kali dalam rentang waktu kurang dari 24 jam.

Tabel 3. Rata-rata persentase hambatan

\begin{tabular}{clc}
\hline No. & \multicolumn{1}{c}{ Perlakuan } & $\begin{array}{c}\text { Rata-rata } \\
\text { persentase } \\
\text { hambatan } \\
(\%)\end{array}$ \\
\hline 1 & $\begin{array}{l}\text { Aquades (kontrol } \\
\text { negatif) } \\
\text { Asap cair suren } \\
6.25 \%\end{array}$ & $0.00 \mathrm{c}$ \\
3 & $\begin{array}{l}\text { Asap cair suren } \\
12.5 \%\end{array}$ & $0,00 \mathrm{c}$ \\
4 & $\begin{array}{l}\text { Asap cair suren } \\
25 \%\end{array}$ & $0,00 \mathrm{c}$ \\
5 & $\begin{array}{l}\text { Asap cair suren } \\
50 \%\end{array}$ & $75.01 \mathrm{~b}$ \\
6 & $\begin{array}{l}\text { Asap cair suren } \\
100 \% \\
\text { Amoksisilin } \\
\text { (kontrol positif) }\end{array}$ & $100,00 \mathrm{a}$ \\
\hline
\end{tabular}

Ket: Angka - angka yang berada pada baris yang sama dan diikuti oleh huruf yang sama berarti tidak berbeda nyata berdasarkan uji tukey pada taraf kepercayaan 5\%.

Berdasarkan hasil penelitian amoksisilin (kontrol positif) merupakan perlakuan yang memberikan hasil persentase hambatan terhadap pertumbuhan bakteri Xoo paling besar yaitu $100.00 \%$. Perlakuan amoksisilin (kontrol positif) nilainya paling besar $\mathrm{hl}$ ini disebabkan bahan aktif yang terkandung dalam amoksisilin sudah teruji keefektifannya melawan bakteri gram negatif maupun positif Amoksisilin merupakan obat semisintetis yang termasuk dalam antibiotik kelas penisilin (antibiotik beta-laktam). Karena ukurannya lebih kecil sehingga efektif untuk mengendalikan infeksi yang disebabkan oleh bakteri gram negatif. Obat golongan penisilin, menghambat pertumbuhan bakteri dengan mengganggu reaksi transpeptidasi sintesis dinding sel bakteri. (Kaur, 2011; Anisah, 2014; Aryani, 2015).

Perlakuan ini berbeda nyata dengan keenam perlakuan lainnya. Perlakuan 6 yaitu ACS E (asap cair suren konsentrasi 100\%) merupakan perlakuan aplikasi yang memberikan hasil persentase hambatan pertumbuhan bakteri Xoo yang paling besar yaitu $77.70 \%$. Perlakuan ini tidak berbeda nyata dengan perlakuan 5 yaitu ACS D (asap cair suren 50\%) dengan persentase hambatan $75.01 \%$. Persentase baru terbentuk mulai pada konsentrasi $50 \%$ dan $100 \%$ artinya pada konsentrasi tersebut asap cair suren mampu menghambat pertumbuhan bakteri. Hal ini disebabkan asap cair suren memiliki aktifitas antibakteri pada konsentrasi optimum tertentu untuk menghambat aktifitas bakteri Xoo.

Akan tetapi perlakuan Perlakuan 6 yaitu ACS E (asap cair suren konsentrasi $100 \%$ ) berbeda nyata dengan perlakuan 1 yaitu kontrol (aquades kontrol negatif), perlakuan 2 yaitu ACS A (asap cair suren 6.25\%), perlakuan 3 yaitu ACS B (asap cair suren $12.5 \%$ ) dan perlakuan 4 yaitu ACS C (asap cair suren 25\%). Perlakuan 1 Aquades (kontrol negatif) tidak akan menghambat pertumbuhan bakteri Xoo, karena media NA hanya digunakan untuk menumbuhkan bakteri tanpa diberi zat anti bakteri baik asap cair suren maupun amoksisilin, sehingga bakteri tumbuh 
tanpa ada hambatan karena memenuhi kondisi lingkungan sesuai dengan syarat tumbuh bakteri Xoo (OEPP/EPPO, 2007). Aplikasi asap cair suren pada konsentrasi $6.25 \%, 12.5 \%$ dan $25 \%$ belum mampu menghambat pertumbuhan bakteri. Hal ini diduga asap cair suren memiliki aktifitas antibakteri pada konsentrasi optimum tertentu dan dikarenakan kualitas dari asap cair suren yang digunakan tidak melalui proses destilasi terlebih dahulu (Fauzan, 2017).

\section{KESIMPULAN DAN SARAN}

\section{Kesimpulan}

Berdasarkan hasil penelitian ini dapat disimpulkan bahwa: Aplikasi Asap Cair Suren berpengaruh terhadap parameter diameter hambatan, luas zona hambatan, dan persentase hambatan bakteri Xanthomonas oryzae pv. oryzae secara in vitro. Konsentrasi Asap Cair Suren $50 \%$ dan 100\% merupakan konsentrasi yang dapat diaplikasikan secara in vitro, karena mulai mampu menghambat perkembangbiakan bakteri Xanthomonas oryzae pv. oryzae secara in vitro.

\section{Saran}

\begin{abstract}
Penelitian ini merupakan penelitian eksperimen labolatorik, sehingga perlu adanya penelitian lanjutan tentang; peningkatan frekuensi waktu aplikasi jumlah konsentrasi asap cair suren yang akan diberikan, aplikasi menggunakan asap cair dari jenis tanaman lain serta dilakukan penelitian secara in vivo terhadap tanaman padi.
\end{abstract}

\section{DAFTAR PUSTAKA}

Anisah, Kurnia. 2014. Analisis komponen kimia dan uji antibakteri asap cair tempurung kelapa sawit (Elaeis guineensis jaqk.) pada bakteri staphylococcus aureus dan pseuodomonas aeruginosa. Skipsi. Universitas Islam Negeri Syarif Hidayatulloh. Jakarta.
Anisah., Rahayu, T. 2015. Media alternative untuk pertumbuhan bakteri menggunakan karbohitrat yang berbeda. Seminar Nasional XII Pendidikan Biologi FKIP UNS 2015.Universitas Muhammadiyah Surakarta. Surakarta. Indonesia.

Aryani, D., Mujianti, D, R., Harlianto, D, U, Y, A. 2014. Studi Kajian Kandungan Senyawa Pada Asap Cair Dari Sekam Padi. Prosiding Seminar Nasional Kimia, Isbn: 978602-0951-05-8 Jurusan Kimia Fmipa Universitas Negeri Surabaya. 3-4 Oktober 2015.

Balai pengkajian dan pengembangan teknologi pertanian, 2016. Teknologi budidaya padi.

Erik, B. Smith, MD, Ibrahim J. Raphael, MD, Mitchell G. Maltenfort, PhD, Sittisak Honsawek, MD, Kyle Dolan, BS, Elizabeth A. Younkins, RN. 2013. The Effect of Laminar Air Flow and Door Openings on Operating Room Contamination. The Journal of Arthroplasty 28 : 14821485.

Fauzan., ikhwanus, M, 2017. Pemurnian asap cair tempurung kelapa melalui distilasi dan filtrasi menggunakan zeolite dan arang aktif. Seminar Nasional Sains Dan Teknologi 2017. Fakultas Teknik Universitas Muhamadiyah Jakarta. 2407-1846.

Firman, M, A, A., Bahri, S.,Khairat. 2016 pirolisis kayu pinus (wood fine) dengan katalis Mo/Lempung menjadi bio-oil. Jom FTEKNIK 3 (1).

Herawati, A., 2016, isolasi dan karakterisasi penyebab penyakit hawar daun bakteri (Xanthomonas oryzae pv. oryzae) pada tanaman padi di wilayah Sulawesi utara, perbal Jurnal Pertanian Berkelanjutan Online. 4 (3).

Kaur. S.Preet., Rekha. R., end Sanju. N., 2011. Amoxicillin: A Broad Spectrum Antibiotic International Journal of Pharmacy and Pharmaceutical Sciences . 3 (1) : 0975-1491. 
Lubis, 2013. Kemampuan Bacillus sp. Penghasil ahl-laktonase dalam menghambat proses quorum sensing patogenisitas bakteri fitopatogen. Skripsi. Departemen Biologi. Fakultas Matematika dan Ilmu Pengetahuan Alam. Institute Pertanian Bogor.

Maryani, D., Masduqi, A., moesriati, A, 2014. Pengaruh Ketebalan Media Dan Rate Filtrasi Pada Sand Filter Dalam Menurunkan Kekeruhan Dan Total Coliform. Jurnal Teknik Pomits 3 (2) : 2337-3539. ITS.

OEPP/EPPO. 2007. Xanthomonas oryzae. Bulletin OEPP/EPPO. 37 : 543553.

Pusat pelatihan pertanian. 2015. Pelatiban Teknis Budidaya Padi Bagi Penyuluh Pertanian Dan Babinsa. Pengendalian Hama Terpadu (PHT) Sesuai Dengan Organisme Pengganggu Tanaman (OPT) Sasaran.

Pusat Penelitian Dan Pengembangan Perkebunan 2012, Pestisida nabati, Kementerian Pertanian Badan Penelitian dan Pengembangan Pertanian.

Purwohadisantoso, K., Zubaidah, E., Saparianti, E, 2009, isolasi bakteri asam laktat dari sayur kubis yang Memiliki kemampuan penghambatan bakteri patogen (Staphylococcus aureus, Listeria monocytogenes, Escherichia coli dan Salmonella thypimurium), Jurnal Teknologi Pertanian 10 (1) : $19-27$.

Puspitasari, Monita. 2014. Diskripsi Sifat Khas Bakteri Xanthomonas oryzae pv. oryzae. Program Pasca Sarjana, Program Studi Hama dan Penyakit Tumbuhan Universitas Andalas, Padang.

Rijayanti, R, P. 2014. Uji Aktivitas Antibakteri Ekstrak Etanol Daun Manga Bacang (Mangifera foetida. L) Terhadap Staphylococcus Aureus Secara Invitro. Naskah Publikasi, Universitas Tanjungpura.

Sudir, Nuryanto, B. dan Kadir, T.S. 2012. Epidemiologi, Patotipe, dan
Strategi Pengendalian Penyakit Hawar Daun Bakteri pada Tanaman Padi. Balai Besar Penelitian Tanaman Padi. Iptek Tanaman Pangan 7 (2).

Sullivan, M., Daniells, E., and Southwick, C. 2011. CPHST Pest Datasheet for Xanthomonas oryzae pv. oryzae. USDA-APHIS-PPQ-CPHST.

Tendencia, E. A. .2004. Disk diffusion method. In Laboratory manual of standardized methods for antimicrobial sensitivity tests for bacteria isolated from aquatic animals and environment Chapter 2 : 13-29. Tigbauan, Iloilo, Philippines: Aquaculture Department, Southeast Asian Fisheries Development Center.

Wahyudi, A. T., Meliah, S., Nawangsih, A.A. 2011. Xanthomonas oryzae pv. oryzae Bakteri Penyebab Hawar Daun Pada Padi: Isolasi, Karakterisasi Dan Telaah Mutagenesia Dengan Transposon. Makara. Sains. 15 (1) : 89-96.

Wening, R. H., susanto, U. dan Satoto. 2016. Varietas unggul padi tahan hawar daun bakteri: perakitan dan penyebaran di sentra produksi. Iptek tanman pangan. 11 (2).

Yunus, M. 2011. Teknologi Pembuatan Asap Cair dari Tempurung Kepala Sebagai Pengawet Makanan. Jurnal Sains dan Inovasi 7 (1) : 53- 61. 